\title{
Annual Hours Working in Britain
}

Gregor Gall and David Allsop

\begin{abstract}
Purpose - To survey and investigate the extent of implementation of annual hours working in Britain and its impact upon employers, organisation and employees.

Design/methodology/approach - To deploy secondary data and sources to establish an overview of the salient issues.

Findings - Although there has been a growth in the extent of annual hours working in the last decade, the rate of growth has slowed and this is related to the reduction in extant organisations that may consider introducing annual hours in tandem with the problems associated with annual hours working.

Research implications - Issues of working time remain a key area of contestation between employers and employees, particularly as in recent years coercive competitive pressures on organisations have increased whilst a discourse about 'family-friendly' working time polices has emerged.

Practical implications - The plaudits of management consultants and policy groups concerning annual hours working are revealed to be rather one-sided, with considerable problems emerging for employers and employees alike.

Originality/value - Brings together an array of data to build up an analysis of annual hours working.

Keywords - Working time, new management techniques, employee interests, United Kingdom Paper type - Literature review
\end{abstract}

\section{Details on Authors}

Gregor Gall is Professor of Industrial Relations at the Centre for Research in Employment Studies at the University of Hertfordshire. He is the author of three books and over fifty refereed articles on industrial relations as well as editor of two volumes on union organising.

David Allsop is a Principal Lecturer in Human Resource Management in the Department of Human Resources and Strategy at the University of Hertfordshire. He is completing a doctoral thesis on industrial relations in the mining industry in Britain, having previously worked as a miner. 


\section{Annual Hours Working in Britain}

Gregor Gall and David Allsop

\section{Introduction}

The emergence of annual hours working has been viewed by some commentators as one of the most notable recent developments in temporal flexibility in Britain (see, for example, IDS 2004). From relative obscurity in the early 1980s, 'annual hours' is now a relatively well-known technique of organising working time in Britain. A leading management consultant has argued:

Any one who has ever tried it knows how difficult it is to match staff deployment to the fluctuating needs of a business - and to produce rosters that don't contain some degree of over- or under-staffing. As a result, many enterprises operate regimes that have poor productivity, inflexibility and costly overtime payments at their core. Annual Hours ... has already helped hundreds of enterprises to eliminate these wasteful practices by transforming the way they think and operate. (Smart Human Logistics 2004),

Meanwhile, the DTI (2005) in association with the CBI and TUC, and the CIPD (see, for example, Stredwick and Ellis 2005) as well as a number of newspaper commentators (see, for example, Daily Telegraph 11 April 2005, Newquest Regional Press 15 February 2005, Observer 18 April 2004) have put forward annual hours $(\mathrm{AH})$ as an antidote to both the long working hours culture in Britain and as a means to meet demands for 'work-life balance' and 'family-friendly' working arrangements whilst maintaining economic productivity.

The basic principle of $\mathrm{AH}$ is that, instead of defining working time on the basis of the standard working week, e.g., 39 hours, working hours are distributed out over the whole year according to worked-out plans. In its simplest form, the calculation of $\mathrm{AH}$ is based on the number of working weeks in the year multiplied by the number of working hours per week minus holidays. Most $\mathrm{AH}$ systems have a number of rostered hours (the majority) and a number of unrostered hours (the minority) to allow for maximum flexibility. Employees are paid on a weekly or monthly basis of one fifty second or one twelfth of their annual salary regardless of the actual number of hours worked that month. Some schemes have additional hours called 'reserve' or 'banked' hours. 
However, $\mathrm{AH}$ are a fairly contentious and controversial technique of doing so for while there appear to be many advantages for employers, there seem to be far fewer benefits for employees. This research note seeks to examine the growth of $\mathrm{AH}$ in terms of the number of organisations deploying the technique, the number of workers covered by their use and the reasons why $\mathrm{AH}$ have been adopted. Finally, the effect on employees is examined to investigate what benefits and drawbacks exist for them given that the main arguments for adopting AH have been concerned with benefits for the employers. The research notes suggests that the slowing up in the rate of organisations adopting $\mathrm{AH}$ is connected to an increasing understanding of the drawbacks and employee dissatisfaction.

The material for this research note is derived from a number of secondary sources such as the publications of the Advisory, Conciliation and Arbitration Service (ACAS), Incomes Data Services (IDS), Industrial Relations Services (IRS), Labour Research Department (LRD) and the Institute of Personnel Management (IPM)/Chartered Institute of Personnel Management (CIPD) as well as coverage of salient developments in the quality press like the Financial Times and the Guardian and among regional daily broadsheets. Whilst there are a number of weaknesses in the robustness of the data generated using such a method, this data can help supplement other data which itself is not without weaknesses so that a fuller, multi-component picture of $\mathrm{AH}$ can be built up.

\section{Growth in Annual Hours}

Towards the end of the 1980s, most commentators agreed that the use of AH was very small, albeit growing (ACAS 1988, CBI 1989, Desmons and Vidal Hall 1987, IDS 1988, IRS 1991, Marsh 1991:46). By the mid- to late 1990s, IRS (1996b:4, 1998a:4) reported not only continued but accelerated growth, and LRD (1993:7) noted that: 'the idea is now being taken up by a wider range of employers'. By the turn of the new decade, LRD (2000:10) found that 48 of its 215 workplace respondents to its survey on working time experienced some use of AH. In 2002, IDS 
(2002:1) reported that: 'nearly one in twenty full-time employees are now covered by [annual hours]' and Bell and Hart (2001:2-3, 2003:75) talked of: 'A common view is that there will be a major growth of interest beyond the pioneering companies' with:

[A] number of major manufacturing and service companies as well as public sector enterprises hav [ing] introduced AHCs [annualised hours contracts] in recent years has served to stimulate interest in their potential for achieving a more adaptable labour market.

Finally, the fifth Workplace Employment Relations Survey (Kersley et al. 2005:29-30) reported that 6\% of workplaces with ten or more employees used $\mathrm{AH}$ for some of their employees, while in its panel survey of establishments with ten or more employees between 1998 and 2004 reported that the use of AH by non-managerial employees increased from $8 \%$ to $13 \%$. The source book of the fifth Workplace Employment Relations Survey (Kersley et al. 2006:79-80) reported that AH were more popular in the following contexts: larger workplaces and workplaces that were part of larger organisations than small or single, independent workplaces; public sector workplaces (14\%) than private sector workplaces (4\%) and where unions were recognised (13\%) than where no unions were recognised $(3 \%)$. Unfortunately, the findings of WERS5 cannot be set in a longitudinal context because the previous WERS/WIRS surveys did not examine the issue of AH. In this regard, the findings of Croucher and Mills (2006:15-17) using the Cranet database are instructive. This database comprises responses for the period 1991-2003 from between 1,000 and 2,500 organisations, primarily in the private sector (71\% in 2003), with the later surveys having a smaller number of respondents. Between 1991 and 1995, Croucher and Mills (2006:16) recorded that the use of $\mathrm{AH}$ fell from around 36\% of organisations to 26\% between 1996 and 2003. Consequently, what can be reasonably concluded from this survey of the existing literature is that some growth in the overall usage of AH has existed since the mid- to late 1980s, albeit it has been of an uneven nature across time and space (sector, workplace size).

Given the absence of standardised and longitudinal data, this research note has, through using secondary sources, identified cases of employing organisations adopting $\mathrm{AH}$ in order to generate a means of assessing the annual and overall rate of adoption. Thus, 276 cases of $\mathrm{AH}$ systems 
being introduced have been identified, with around 85\% being introduced after 1989 (Table 1).

The total number of known employees covered by these reported cases is $436,390(n=206)$. Taking the known numbers, and using an average multiplier to give one indication of the total potential coverage, some 585,000 employees are likely to be covered by the total number of identified cases of AH ( $n=276)$. This represents a considerable increase from the 91 cases covering 85,000 employees found between 1989 and 1996 (see Gall 1996:37). In addition, around eleven other examples were identified of employers considering implementing AH in the period 1997-2004 (see also IRS 1996a:4, 1998:4). The number of management consultants specialising in creating general and bespoke AH packages has also increased markedly in the last ten years. Yet, it is also apparent that the annual rate of additional employing organisations adopting AH has slowed down considerably since the late 1990s. This is likely to be the result of AH no longer being a 'new fad', whereby many of the most responsive or appropriate employing organisations have already adopted it and the drawbacks, including employee resistance, becoming more widely understood (see below).

Table 1: Adoption of Annual Hours by Year

\begin{tabular}{|l|r|r|r|r|r|r|r|r|r|}
\hline Year & Pre-1989 & 1989 & 1990 & 1991 & 1992 & 1993 & 1994 & 1995 & 1996 \\
\hline $\begin{array}{l}\text { No. of } \\
\text { employers }\end{array}$ & 23 & 10 & 11 & 7 & 21 & 16 & 13 & 12 & 17 \\
\hline Year & 1997 & 1998 & 1999 & 2000 & 2001 & 2002 & 2003 & 2004 & 2005 \\
\hline $\begin{array}{l}\text { No. of } \\
\text { employers }\end{array}$ & 25 & 15 & 15 & 8 & 6 & 10 & 11 & 7 & 1 \\
\hline
\end{tabular}

Source: see methodology.

Note: $\mathrm{N}=276$. Year unknown for the other 48 cases.

However, given that the research for this paper deploys only reported cases, the number of cases identified will undoubtedly underestimate the 'true' extent of AH. Thus, using a number of other data sources to judge the extent of AH working is important. Arrowsmith (1998:1-2), using a study of 130 organisations in engineering and 75 NHS trusts covering a quarter of a million employees, reported that the percentage of engineering firms using $\mathrm{AH}$ had increased from $2 \%$ to $8 \%$ between 1995 and 1998 while the corresponding percentages for the NHS trust were 6\% to $18 \%$. Moreover, in a survey of 180 NHS trusts (Health Service Report, Autumn 1998), 43 
reported that they had finalised work on annualised hours and a further 105 said that they were examining it. From the CIPD's (2005:6,7) survey of 585 employing organisations in 2004, 28\% of these organisations had some of their staff working $\mathrm{AH}$ but only $8 \%$ had all of their staff working $\mathrm{AH}$, and the percentage of organisations considering introducing $\mathrm{AH}$ was $3 \%$.

The Confederation of British Industry (CBI) has monitored developments in the implementation of AH since 1998 through its annual Employment Trend Surveys (see Table 2), which covers only private sector employers. This indicates that on average $12 \%$ of respondents have implemented $\mathrm{AH}$ schemes and that $15 \%$ of respondents were at the time of the survey considering implementing AH schemes. Table 2 shows also that the portion of respondents using AH falls over the period 1998-2003. This is most likely explicable by the varying level and type of respondents, where both varied widely through the surveys. Nonetheless, the CBI (2000:29) would appear to be fairly accurate in concluding that AH: 'remained relatively little utilised'.

\section{Table 2: Extent of Actual and Planned Adoption of Annual Hours by Year}

\begin{tabular}{|l|r|r|r|r|r|r|r|r|}
\hline Status/Year & 1998 & 1999 & 2000 & 2001 & 2002 & 2003 & 2004 & 2005 \\
\hline Introduced & $17 \%$ & $12 \%$ & $11 \%$ & $11 \%$ & $14 \%$ & $9 \%$ & $11 \%$ & $11 \%$ \\
\hline Considering & $\mathrm{n} / \mathrm{a}$ & $17 \%$ & $18 \%$ & $7 \%$ & $20 \%$ & $\mathrm{n} / \mathrm{a}$ & $20 \%$ & $8 \%$ \\
\hline No Plans & $\mathrm{n} / \mathrm{a}$ & $71 \%$ & $71 \%$ & $82 \%$ & $67 \%$ & $\mathrm{n} / \mathrm{a}$ & $\mathrm{n} / \mathrm{a}$ & $\mathrm{n} / \mathrm{a}$ \\
\hline
\end{tabular}

Source: CBI (1998-2005).

Note: The annual CBI Employment Trend Surveys covered between 420 and 940 employers in the private sector with between $0.8 \mathrm{~m}$ and $3.5 \mathrm{~m}$ employees.

The Labour Force Survey (LFS) data represents the best available means by which to gain a more accurate picture of the extent of $\mathrm{AH}$ working. Thus, Table 3 indicates that the number of employees whose working hours are organised under AH is much greater as expected. Using the LFS and examining the period 1994-2001, Bell and Hart (2003:66, 76) reported that: 'AHCs [Annual hours contracts] accounted for less than 5 per cent ... of workers. The proportion of workers with AHCs fell to the mid-to-late 1990s but has risen slightly in recent years' with 'some indication of recent trend increases'. But, Bell and Hart (2003:75) also noted: 'the take up [of annual hours] has been relatively modest'. 
While it can confidently be stated that the numbers covered by AH has increased markedly in recent years in regard of the number of employing organisations identified deploying AH for this research note, the LFS data needs to be treated with some caution. The problems with the LFS data are several-fold. First, the second largest group covered, namely teachers that comprise the vast majority of the generic category 'education' (see Table 5), is not covered by AH as defined above and conventionally understood. Teachers have a number of contracted hours or days that are set over a year but these are structured with regard to term times (see also IDS 2005:12-13). The same point applies to other groups within education which have contracted hours like further education college lecturers (see also Gall (1996:38)). Second, it is hard to reconcile the considerable increases and decreases in the numbers covered in such short spaces of time. This may result from changes in how the definition of $\mathrm{AH}$ is constructed. Consequently, the validity and accuracy of the LFS data is brought into serious doubt. Nonetheless, and taking into the likely impact of these caveats, there would still appear to have been an overall decline in the (real) numbers covered by AH from the mid- to late 1990s. Some of the (real) fluctuation in the coverage of $\mathrm{AH}$ is likely to be attributable to the problems of $\mathrm{AH}$ systems leading to some organisations to rescind their use of them for organising working time (as well as the slowing rate of adoption by new organisations).

Table 3: Annual Hours coverage from the Labour Force Survey

\begin{tabular}{|l|l|l|}
\hline Year & $\begin{array}{l}\text { No. of } \\
\text { workers }\end{array}$ & \% of workforce \\
\hline 1990 & n/a & $6.4 \%$ \\
\hline 1994 & $1.95 \mathrm{~m}$ & $9.0 \%$ \\
\hline 1995 & $\mathrm{n} / \mathrm{a}$ & $6.2 \%$ \\
\hline 1997 & $\mathrm{n} / \mathrm{a}$ & $4.0 \%$ \\
\hline 1999 & $0.485 \mathrm{~m}$ & $2.7 \%$ \\
\hline 2001 & $0.842 \mathrm{~m}$ & $4.7 \%$ \\
\hline 2003 & $0.820 \mathrm{~m}$ & $4.6 \%$ \\
\hline 2004 & $0.942 \mathrm{~m}$ & $4.7 \%$ \\
\hline 2005 & $\mathrm{n} / \mathrm{a}$ & $4.7 \%$ \\
\hline
\end{tabular}

Source: LFS (in IDS 1993, 1999, 2002, 2004, 2005, IRS 1998a, TUC 2005). 
In terms of how the extent of $\mathrm{AH}$ in Britain compares with the situation in other European countries, EIRO (2003b:8) reports that while there is no standardised data with which to make a firm judgement, there are four categories which can be formulated. First, countries where AH cover a substantial proportion of workers thought to be approaching a third or more (Denmark, France, Germany and Spain). Second, countries where coverage is relatively widespread, covering a quite low but not insignificant proportion of workers (Belgium, Britain Finland and Italy). Third, countries where $\mathrm{AH}$ exist but do not have wide coverage (Austria, Ireland, the Netherlands, Norway and Sweden). And fourth, countries where AH are virtually non-existent (Greece and Portugal).

\section{Employee Coverage under Annual Hours Systems}

AH systems do not necessarily cover all employees within a employing organisation, with the numbers varying from only a minority of employees to all workers and staff being covered. Both 'extremes' represent only a minority of cases. In 1993, IDS (1993) found the extent of coverage can vary from $8 \%$ of the workforce, where only specialist grades/occupations are involved, to $100 \%$ of all staff in organisations. In 2004, IDS (2004) found some organisations with only $5.5 \%$ and $7 \%$ of employees involved but still ranging up to between $80 \%-100 \%$. However, most commonly between $40 \%-80 \%$ of employees are covered, those employees usually being manual workers in manufacturing, and particularly, in continuous process industries. In semi-continuous manufacturing industries, craft and maintenance staff are more likely to be covered by AH while in the public sector like the NHS, specific grades or occupations like nurses or medical secretaries are covered. The process by which the $\mathrm{AH}$ are introduced often begins with a minority of employees being covered initially before further groups also become covered. For example, IPM (1993:29) reported that $42 \%$ of its 79 respondents intended to enlarge the number of employees covered by their existing AH schemes. Public sector organisations with very small numbers covered by AH report that these were essentially 'trial operations' and that if these proved to be 
successful the operation of $\mathrm{AH}$ would be extended to other employees. Clearly then, there is some potential for greater numbers to be covered by AH within existing schemes.

\section{Sectoral Distribution}

AH systems were originally and predominantly located in continuous and semi-continuous process industries (Beaumont 1993, IDS 1993, IPM 1993, IRS 1996b) with some limited movement into general manufacturing and private and public services organisations. Tables 4 and 5 highlight that while the initial predominance of manufacturing has been maintained, there are some increasingly significant indications of moves towards take-up in the service and public sectors, suggesting that longer hours of business and sharp fluctuations in demand are leading some employers to use AH. Indeed, by $2005 \mathrm{AH}$ contracts had become more prevalent in the public, than private, sector, with $5.1 \%$ of public sector employees covered compared to $3.8 \%$ in the private sector in 2005 according to a TUC (2005) analysis of the autumn 2004 LFS data. And, given the relatively large size of single organisations in the public sector, a small number of organisations account for a disproportionately large number of employees covered by AH. In 2003, and based on Table 5, these small number of public sector organisations (see, for example, Table 4) accounted for $38 \%$ of AH coverage by employees.

Table 4: Industrial Sector Distribution of Reported Annual Hours Schemes

\begin{tabular}{|l|r|}
\hline Sector & $\begin{array}{l}\text { Number of } \\
\text { organisations }\end{array}$ \\
\hline Education & 1 \\
\hline Electricity, gas \& water supply & 8 \\
\hline Manufacturing & 133 \\
\hline Health and social work & 27 \\
\hline $\begin{array}{l}\text { Transport, storage \& } \\
\text { communications }\end{array}$ \\
\hline $\begin{array}{l}\text { Other community, social \& } \\
\text { personal }\end{array}$ \\
\hline Wholesale, retail \& motor trade & 3 \\
\hline Financial intermediation & 10 \\
\hline Construction & 0 \\
\hline Public administration \& defence & 20 \\
\hline Hotels \& restaurants & 3 \\
\hline
\end{tabular}




\begin{tabular}{|l|r|}
\hline $\begin{array}{l}\text { Real estate, renting \& business } \\
\text { activities }\end{array}$ & 11 \\
\hline Mining \& quarrying & 4 \\
\hline Total & 236 \\
\hline
\end{tabular}

Source: see methodology.

Note: $\mathrm{N}=276$. Sector unknown for the other 40 cases.

Table 5: Employee Coverage by Annual Hours in the Labour Force Survey by Sector

\begin{tabular}{|l|r|r|r|}
\hline Sector/Date & \multicolumn{1}{l|}{$\begin{array}{l}\text { Spring } \\
1999\end{array}$} & \multicolumn{1}{l}{$\begin{array}{l}\text { Spring } \\
\text { 2001 }\end{array}$} & \multicolumn{1}{l}{$\begin{array}{l}\text { Spring } \\
2003\end{array}$} \\
\hline Education & 129,000 & 147,000 & 127,000 \\
\hline Electricity, gas \& water supply & 4,700 & 13,000 & 9,000 \\
\hline Manufacturing & 104,400 & 202,000 & 167,000 \\
\hline Health and social work & 37,200 & 80,000 & 97,000 \\
\hline $\begin{array}{l}\text { Transport, storage \& } \\
\text { communications }\end{array}$ & 43,800 & 75,000 & 74,000 \\
\hline $\begin{array}{l}\text { Other community, social \& } \\
\text { personal }\end{array}$ & 18,000 & 35,000 & 39,000 \\
\hline Wholesale, retail \& motor trade & 40,200 & 90,000 & 100,000 \\
\hline Financial intermediation & 22,000 & 40,000 & 41,000 \\
\hline Construction & 16,300 & 38,000 & $\mathrm{n} / \mathrm{a}$ \\
\hline Public administration \& defence & 27,800 & 48,000 & 49,000 \\
\hline Hotels \& restaurants & 6,300 & 13,000 & 21,000 \\
\hline $\begin{array}{l}\text { Real estate, renting \& business } \\
\text { activities }\end{array}$ & 30,200 & 58,000 & $\mathrm{n} / \mathrm{a}$ \\
\hline Mining \& quarrying & 2,500 & 2,500 & $\mathrm{n} / \mathrm{a}$ \\
\hline
\end{tabular}

Source: IDS (1999, 2002, 2004)

Note: The figures for the three years are for current employees at the census date.

Regardless of the sectoral dimension, the majority of organisations identified to be using $\mathrm{AH}$ for the research for this article employed more than 50 employees $(87 \%, \mathrm{n}=235)$ and $59 \%$ were found to employ more than 250 employees. This can be taken to suggest that smaller organisations with less than 50 employees, and probably with only one workplace, were able to create sufficient task and temporal flexibility which then significantly reduced their desire or 'need' to introduce AH (see, for example, Forth et al 2006:84, 87-88).

\section{Employer Objectives}

The basic objectives of employers introducing $\mathrm{AH}$ have been commonly argued by commentators and consultants alike to be concerned with minimising unit labour costs, increasing productivity and enhancing labour flexibility through the alignment of the requirement 
of staff with predicted demands for products and services. The particular nature or configuration of employers' attempts to 'minimise unit labour costs' concern increasing the congruity between paid for hours of labour and productive hours of work. Thus, IDS (2004:1) commented: 'The objective is that staff are at work when the business needs them to be and not at work when demand is slack'.

For the private sector, this means trying to increase or maintain profitability within a competitive and coercive environment of increasing competition, new competitors, falling demand and overproduction, while for the public sector organisations, this means operating in the context of reductions in funding and tighter financial controls on how funding is spent and resources are allocated. Arrowsmith (1998:2) argued that:

In the NHS, working time flexibility has also long been a prime concern due to the need to reconcile permanent opening with variable levels of demand. Likewise, the need to make working time arrangements more acceptable to the workforce owing to recruitment and retention problems associated with relatively low pay, demanding work and the high proportion of 'unsocial hours' has been an important additional factor. Especially significant, however, has been the response of local managers to a regime of tight cash limits and bighly centralised (but under-funded) pay settlements for groups such as nurses. In effect, if they are to live within their budgets, they bave bad little option but to focus on the variables in labour costs under their control, which means the numbers of workers employed and the bours that they work.

Both these processes in the private and public sectors are the result of broad but interrelated economical and political changes; recession and the restructuring of capital and the move to neoliberalism in governmental policies.

If the specific reasons for the introduction of $\mathrm{AH}$ are examined, they are many and varied. The most common aims of, and reported reasons for, introducing AH have been the reduction in overtime/special payments, reducing sickness/absence rates, responding to increasing competition, the introduction of wider changes, reductions in the working week and coping with variable demand across the year (see also IPM 1993).

However, we can break these reasons down further. AH can allow labour costs to be more easily predicted, and facilitate the matching of production/service requirements and customer demand 
to staffing levels thus reducing unproductive staff time and the need to hire temporary staffs. Some employers believe that so-called 'presentee-ism' of non- or in-effective deployment of staff time can be lessened through using $\mathrm{AH}$ systems. AH can also generate the greater use of expensive machinery, reducing its downtime and more quickly recouping its costs, and forward planning by management. For example, an AH scheme can be used to end the need for trade holiday and Christmas/New Year shutdowns. Hours of overtime work and overtime payments in Britain continue to be relatively high compared with other countries (EIRO 2003a:15-16). Thus, $\mathrm{AH}$ provides an attractive means by which overtime costs can be reduced or eliminated where employers feel they are prohibitively expensive or habitual or where work is stretched out to incur overtime pay. Likewise $\mathrm{AH}$ can be used to reduce or eliminate the use of special premium payments (e.g. unsocial working hours and call-out pay) and the use of temporary workers. The AH technique has also been used as one method of meeting union demands for shorter working weeks and greater holidays which are acceptable to managements by virtue of the changes being essentially self-financing in that $\mathrm{AH}$ can be used to reduce manning levels and implement redundancies. Pressure from governmental bodies (national, European Union) in the form of compulsory competitive tendering (CCT), 'family-friendly' policies (under the Employment Relations Act 1999 and Employment Act 2002) and the Working Time Regulations (WTR) have also led some organisations to reconsider how they organise their working time (IRS 1998b). However, it is still not entirely clear much impact the WTR have had here, given the widespread use of optout clauses (Barnard et al. 2002, BMRB Social Research 2004, TUC 2003). The same is true for family-friendly policies, in that, $\mathrm{AH}$ can also be argued to be contrary to their intention, particularly for women. Finally, Bell and Hart (2003:72-75) suggest that the pursuit of a higher degree of utilisation of employers' plant, machinery and space is also an implicit or underlying reason for the implementation of AH. Here, the specific issue is to reduce the 'downtime' of relatively expensive capital investments.

It is important to note that a significant number of identified organisations $(58 \%, n=276$, see Table 1) have either used the opportunity of introducing $\mathrm{AH}$ to introduce other changes such as 
flexible work practices, multi-skilling, teamwork and performance-related pay and new pay structures, or introduced AH as part of a wider package of restructuring (IPM 1993, IRS 1991, 1996a, 1998a, IDS 1999, 2004). This is because the organisations were, according to their managements, reaching a turning point in their history and operations that required extensive changes in work organisation to meet the challenges they faced. Therefore, at the point of introducing $\mathrm{AH}$ it was felt by many managers that such large changes would require changes in attitudes and 'company cultures' which would also facilitate the introduction of equally farreaching and deep-seated changes in work practices and organisation. Thus one personnel manager believed that AH 'served as a springboard for introducing a broader packet of change' (IPM 1993:24). Reflecting their contentious nature, and their inclusion as part of restructuring or change programmes, AH systems have been introduced with relatively generous payment settlements, of either one-off payments or higher than usual annual pay awards (Gall 1996:48). For example, at British Nuclear Fuels, $\mathrm{AH}$ was part of a package of changes in work practices that were accepted by the workforce in return for a $16 \%$ pay increase over 18 months (Independent 13 September 1999). IDS (1999:4) termed these payments as 'sweeteners'.

\section{Problems in Gaining Desired Outcomes}

Despite the stated or alleged benefits, employers have found that the technique of $\mathrm{AH}$ is not a universal panacea for their problems, in particular, because AH itself has certain disadvantages. Commonly reported problems include the length of time negotiating and consulting over their introduction, the complexity of working out the details of working hours with the different types of hours (e.g., rostered/unrostered) and keeping track of the number of hours worked by individual employees as well as accurately predicting peak and troughs in demand. Furthermore, and after implementation employers have found there is also a distinct disinclination of employees to work or pay back unused hours while, alternatively, some organisations find themselves with such serious downturns in demand for their goods or services that they end up paying for working hours they do not wish to use. Moreover, the implementation of AH has not 
always succeeded in eliminating overtime. Sometimes this arises for reasons of hard to predict increases in demand, production problems in meeting demand or having used up the $\mathrm{AH}$ entitlement before the year as ended as well as a result of tightly defined operational procedures where agreements have been negotiated with trade unions. Following these problems, some organisations introduced additional 'bank' hours (like BMW) or maintained their provisions for overtime working (see Table 6, IPM 1993:24) while a few have ended their AH systems and opted for other forms of flexible working ( $\mathrm{n}=43$ for this research). Consequently, IDS (2004:1, 2002:3), commented that: 'AH systems tend to reduce rather than eradicate overtime working' and that 'To realise the full benefits ... much depends on a culture change on the part of managers and employees in how they regard overtime'. Indeed, because Bell and Hart (2003:76) concluded that $\mathrm{AH}$ involve heavy transitional costs, i.e. evaluating whether $\mathrm{AH}$ are suitable and employer-worker negotiations, an increase in basic pay and the payment for un-worked hours, they identified a limited number of situations where AH may be beneficial. Finally, some employing organisations using $\mathrm{AH}$ have also noticed that the desire to use no more than the allotted number of hours has meant that the priority given to organisational production and service demands has led to non-production/service work like training being downgraded (see, for example, Personnel Today 28 February 1995).

Table 6 Retention of Overtime Systems under Annual Hours

\begin{tabular}{|r|r|l|}
\hline Year & $\begin{array}{l}\text { Number of } \\
\text { organisations } \\
\text { in survey }\end{array}$ & $\begin{array}{l}\text { \% with } \\
\text { Overtime } \\
\text { provisions }\end{array}$ \\
\hline 1993 & 24 & $50 \%$ \\
\hline 1996 & 34 & $38 \%$ \\
\hline 1999 & 28 & $39 \%$ \\
\hline 2002 & 34 & $41 \%$ \\
\hline 2004 & 36 & $47 \%$ \\
\hline
\end{tabular}

\section{Benefits and Drawbacks for Employees}


Many commentator and consultant proponents of $\mathrm{AH}$ comment that there are numerous employee benefits to be derived from such a system. These include better structured and organised working time, reductions in work hours, more usable and increased leisure time, more holiday time, improved basic pay, predictable weekly or monthly take home pay and stability of earnings throughout the year, harmonisation of conditions between manual and white-collar workers, and increased job security. However, it is apparent that some doubt can be cast over these alleged benefits (Heaton and Linn 1987, Marsh 1991, LRD 1994, 1996, 1998).

Commonly reported drawbacks of $\mathrm{AH}$ range from loss of (overtime) earnings, restrictions on the choice of when to take holidays, reduced manning levels, and inflexible shift rotas. Other reported drawbacks are new unconventional shift patterns to cover reductions in number of hours, disrupted and restricted leisure time such as longer working hours in the summer and shorter working hours in the winter, and possible job losses. Moreover, three other prominent drawbacks were discrimination against women who were unable to arrange, or had difficulty in arranging, childcare and domestic responsibilities, short notice call-ins with only 24 or 48 hours' notice and what were previously voluntary additional hours in the form of overtime now becoming involuntary.

The precise details of how an individual AH system works with regard to its benefits/drawbacks for employees can depend on the particular details of the AH scheme, the nature of production/service which the employees provide and the details of the packages of overall change. Therefore it is possible that some employees may experience benefits, but on balance its appears that $\mathrm{AH}$ works, to some considerable extent, to the detriment of employees' interests. Thus, for example, the GMB (1993) reported: 'The results ... vary from the very favourable to complete failure. A great deal depends on the industry' while the Lothian Trade Union Centre argued: 'Proposals to introduce annual hours systems of organising working time tend to be viewed with suspicion. However, if an appropriate set of negotiated standards can be secured, various benefits can be expected to accrue' (White 1992:33). 
Nonetheless, AH schemes have been the subject of many, including some high profile, industrial disputes like those respectively at Thermphos (Chemical News \& Intelligence 7 February 2005), Dairy Crest (Gloucester Citizen 31 July 2004), Baxters food manufacturers (Press and Journal 15 December 2003), Birmingham International Airport (Birmingham Evening Mail 8 July 1999) and Lyle and Scott woollen manufacturers in 1997, and a number of strikes like those by check-in staff at British Airways in mid-2003, car workers at Peugoet's Coventry plant in 2000 (Coventry Evening Telegraph 13 July 2000), and at Rover cars between 2003 andc2004 (Socialist Worker 13 December 2003, 24 January 2004). Additionally, AH has been rejected in ballots at Harris Distribution (Birmingham Evening Mail 30 July 1997), Delta Electrical Systems (Birmingham Evening Mail 7 February 2002), Spence Bryson (Belfast Telegraph 11 April 2002), the Birmingham Repertory Theatre (The Stage 2 November 2000) and a Tyneside shipbuilder (Newcastle Journal 30 June 2000) (for other examples, see Gall 1996:48). These disputes reflect both the fear of the deleterious impact of $\mathrm{AH}$ prior to their introduction and the problems encountered after their introduction. More generally, these disputes indicate in a stark manner that the organisation of working time and the commodification of time remain significant causes of tension and conflict between employers and employees (see Heyes 1997:65-68). However, employees' reluctant acceptance of the introduction of $\mathrm{AH}$ elsewhere rests on a combination of pay awards, job insecurity (i.e., the prospect of job losses through disinvestment, no further investment or loss of market share) and unilateral imposition by management (e.g., Flymo, Spennymoor (Northern Echo 24 May 2000) and see also Gall (1996:48) for other examples).

In the light of this discussion, a number of points emerge. Firstly, it is unlikely that many proposals to introduce $\mathrm{AH}$ will emerge from employees under the right to request flexible working legislation that has been in force since early 2003. Indeed, no cases have been reported by Holt and Grainger (2005) or Palmer (2004). Secondly, with AH being more prevalent amongst unionised workers than amongst non-union workers $-6.9 \%$ as opposed to $4.4 \%$ in 2005 , according to the TUC (2005) - it is more likely that the introduction of AH schemes will meet 
some degree of opposition because unionised workforces are more able to collectively organise opposition. Lastly, issues of working time have moved up the agenda of workers' employment concerns, such that when the then GMB union general secretary, Kevin Curran, pronounced in the British Airways dispute in 2003 that 'time is the new money', he reflected the view that workers were increasingly unlikely to accept working hours that were regarded as anti-social even if there was adequate remuneration in return. Consequently, when faced with the introduction of $\mathrm{AH}$ schemes, workers attach increasing importance to being able to maintain working hours that allow family and social interaction to continue with those working '9-5', Monday-Friday based working hours.

\section{Jointly Negotiated Common Benefits?}

The widespread practice of extensive negotiation with workers' representatives over the introduction of $\mathrm{AH}$ systems suggests that there is the potential for the articulation and integration of employer and employee interests so that these become 'common' or 'shared' interests in the vein of 'mutual gain-sharing'. Here the argument runs that such extensive alteration of working time involved in $\mathrm{AH}$ behoves that both parties can secure advantage for their interests from the AH system. (If this is not the case, either or both would withdraw their initiative/cooperation.) The most obvious type of jointly determined benefit is that of increased (plant and labour) productivity per hour leading to the ability to pay out higher wages. Moreover, the process of collective bargaining over AH may reinforce the validity and legitimacy of the codetermination of workplace governance.

However, the possibility of such outcomes are limited by several factors where the existence of negotiation per se should be assumed to indicate high levels of positive and willing agreement and consent on the part of employees. The 'make or break' nature of the management agenda for the organisation under which $\mathrm{AH}$ are often introduced does not induce extensive latitude for manoeuvre within which an array of different collective bargaining outcomes can be 
accommodated. Even where there is a degree of management subterfuge about the extent of the need for an AH system actually being 'make or break' for the organisation, the rhetoric and intent exemplify a management unilateralist bent to coerce the employees into managerially determined 'acceptable outcomes'. This is reinforced by the extent of one-off compensatory payments to compel agreement and the extent of industrial disputes over AH (on both, see also Gall (1996)), which indicate that different forms of coercion are being applied by employers. Moreover, the outcome of the disputes over $\mathrm{AH}$ seldom result in employees gaining the realisation of their agenda.

Critically, it is the general imbalance of power between capital and organised labour in the contemporary period which helps explain the nature of the outcome of the negotiations over AH. Employers are generally unable to merely introduce AH unilaterally because they require worker cooperation and consent. However, the power imbalance allows employers to predominantly determine the outcome of the nature of the introduction of $\mathrm{AH}$ so that even where there is agreement and consent, it is of a sullen and reluctant nature, compelled by lack of viable alternatives as a result of the paucity of workers' power resources.

\section{Conclusion}

While $\mathrm{AH}$ remains a relatively minor feature of the way working time is organised in Britain, it has attracted considerable, if not disproportionate, amount of attention from commentators because it represents a relatively radical and innovative method of reorganising the temporal dimension of work. Nonetheless, AH has become more common since the early to mid-1990s despite the many problems associated with its nature and implementation and its inability to deliver on the promises made of it. Thus, Bell and Hart (2002:21, 2003:76) concluded after examining its costs and benefits that: 'It is doubtful whether future interest will extend significantly beyond the modest workforce numbers already covered' and that 'Future moves towards $[\mathrm{AH}]$ are likely to be concentrated among organisations that perceive the benefits of the 
... advantages to outweigh the high costs of implementation'. Even here, Bell and Hart (2003:76)

noted that: 'The evidence points to a limited likelihood of future growth'. Thus, Brewster's (1992:111) comment over a decade ago that: 'Annual hours arrangements are not so far widespread but they are becoming more common' still appears broadly correct.

Like many new developments in employment and so-called 'new management' techniques, $\mathrm{AH}$ has received many plaudits and much high-profile publicity without any accompanying critical examination. This research note has attempted to provide such an examination, whereby a key point that emerges is that because $\mathrm{AH}$ represents such a dramatic and radical change in working time organisation with consequent impacts on the organisation of work per se, workers' interests and their relations with management, it has a considerable capacity to cause disruption. This is likely to further disincline many possibly appropriate employers from contemplating introducing the system. For workers, that the introduction of $\mathrm{AH}$ is derived from management initiative has often become a cause for their concern.

\section{References}

ACAS (1988) Labour flexibility in Britain; the ACAS survey, ACAS, London.

Arrowsmith, J. (1998) 'Annualised hours agreements: service sector leads the way' Eironline, European Industrial Relations Observatory, Dublin.

Barnard, C., Deakin, S. and Hobbs, R. (2002) 'The use and necessity of Article 18.1(b)(i) of the Working Time Directive in the United Kingdom' (an unpublished European Union report), Cambridge University, Cambridge.

Bell, D. and Hart. R. (2001) 'Annualised hours contracts' University of Stirling, unpublished paper.

Bell, D. and Hart. R. (2002) 'Annualised hours contracts: the way forward in labour market flexibility?' University of Stirling, unpublished paper.

Bell, D. and Hart. R. (2003) 'Annualised hours contracts: the way forward in labour market flexibility?’ National Institute Economic Review, 185:64-77.

Beaumont, P. (1995) The Future of Employment Relations, Sage, London.

Brewster, C. (1992) 'Managing industrial relations' in Towers, B. (ed.) A Handbook of Industrial Relations Practice: practice and law in the employment relationship, Kogan Page, London.

BMRB Social Research (2004) A Survey of Workers' Experiences of the Working Time Regulations, EMAR Study 31, DTI, London.

CBI (1989) Hours of Work in British Business: A CBI survey, CBI, London.

CBI (1998-2005) Employment Trends Survey, CBI, London.

CIPD (2005) Flexible Working: Impact and Implementation - an employer survey, CIPD, London.

Croucher, R. and Mills, T. (2006) 'Trends in time and locational flexibility in British organisations, 1989-2004', Employment Relations Occasional Paper, DTI, London.

Desmons, G. and Vidal Hall, T. (1987) Annuals Hours: a study of annual hours arrangements in the UK, Industrial Society, London. 
DTI (2005) Managing Change: Practical Ways to Reduce Long Hours and Reform Working Practices (in association with the TUC and the CBI), Department of Trade and Industry, London. EIRO (2003a) 'Overtime in Europe' Eironline, European Industrial Relations Observatory, EIRO (2003b) 'Annualised hours in Europe' Eironline, European Industrial Relations Observatory,

Dublin, pp1-15, August (http://www.eiro.eurofound.eu.int/2003/08/study/tn0308101s.html). Forth, J., Bewley, H. and Bryson, A. (2006) Small and Medium-sized Enterprises: findings from the 2004 Workplace Employment Relations Survey, DTI, London.

Gall, G. (1996) 'All Year Round: The growth of annual hours in Britain' Personnel Review, 25/3:3552.

GMB (1993) Human Resource Management - a new management agenda, GMB. London.

Heyes, J. (1997) 'Annualised hours and the knock: the organisation of working hours in a chemical plant' Work, Employment and Society, 11/1:65-82.

Heaton, N. and Linn, I. (1989) Fighting Back: a report on the shop stewards response to new management techniques in TGWU Region 10, TGWU Region/Northern College.

Holt, H. and Grainger, H. (2005) Results of the second flexible working employee survey, Employment

Relations Research Series, No. 39, EMAR, Department of Trade and Industry, London.

IDS (1988) 'Reorganising Working Time', IDS Study 417.

IDS (1993) 'Annual Hours' IDS Study 544.

IDS (1996) 'Annual Hours' IDS Study 604.

IDS (1999) 'Annual Hours' IDS Study 674.

IDS (2002) 'Annual Hours' IDS Study 721.

IDS (2004) 'Annual Hours' IDS Study 767.

IDS (2005) 'Understanding reward: the use of annual hours systems' IDS Pay Report, 928:12-14.

IRS (1991) 'Annualised hours' Industrial Relations Review and Report, 488:4-8.

IRS (1996a) 'Flexible working hours - a survey of practice' IRS Employment Trends, 608:4-10.

IRS (1996b) 'Annual hours brings widespread change to chemicals' IRS Employment Trends, 618:3.

IRS (1998a) 'Flexing the clock part 1: the use of annual hours' IRS Employment Trends, 654:4-10.

IRS (1998b) 'Flexing the clock part 2: the experiences of annual hours' IRS Employment Trends, 655:6-10.

IPM (1993) 'Annual hours working in the UK' Issues in People Management, IPM, London.

Kersley, B., Alpin, C., Forth, J., Bryson, A., Bewley, H., Dix, G., and Oxenbridge, S. (2005) Inside the Workplace: First findings from the 2004 Workplace Employment Relations Survey, DTI, London.

Kersley, B., Alpin, C., Forth, J., Bryson, A., Bewley, H., Dix, G., and Oxenbridge, S. (2006) Inside the Workplace: Findings from the 2004 Workplace Employment Relations Survey, Routledge, London.

LRD (1993) 'Annual hours' Bargaining Report, 124:7.

LRD (1994) Working Time: An LRD Guide to the New Directive, Labour Research Department, London.

LRD (1996) Flexible Working Time: A Guide for Trade Unionists, Labour Research Department, London.

LRD (1998) Working Time: A Trade Unionist's Guide to the New Regulations, Labour Research Department, London.

LRD (2000) 'Overtime working - still the employers' flexible friend' Workplace Report, 201:7-11.

Marsh, C. (1991) Hours of Work of Men and Women in Britain, HMSO, London.

Palmer, T. (2004) Results of the first flexible working employee survey, DTI Employment Relations

Occasional Papers 04/703, Department of Trade and Industry, London.

Smart Human Logistics (2004) Online brochure section on annual hours, accessed 12 August at

$<$ smarthumanlogistics.com $>$.

Stredwick, J. and Ellis, S. (2005) Flexible Working, CIPD, London.

TUC (2003) 'It's about time ... to end the long hours opt-out' available at <tuc.org.uk/work_life/tuc-7285-f0.cfm>.

TUC (2005) Challenging times: flexibility and flexible working in the UK, TUC, London, 16 December (available on TUC website).

White, T. (1992) 'Annualised hours: Who stands to benefit?' Scottish Trade Union Review, 55:33. 